\title{
Commitment and the Second-Person Standpoint
}

(forthcoming in Zeitschrift für philosophische Forschung)

\author{
Janis David Schaab \\ Janis.d.schaab@gmail.com \\ www.jdschaab.weebly.com
}

English Abstract:

On Chang's voluntarist account of commitments, when we commit to $\varphi$, we employ the 'normative powers' of our will to give ourselves a reason to $\varphi$ that we would otherwise not have had. I argue that Chang's account, by itself, does not have sufficient conceptual resources to reconcile the normative significance of commitments with their alleged fundamentally volitional character. I suggest an alternative, second-personal account of commitment, which avoids this problem. On this account, the volitional act involved in committing is one of holding ourselves accountable, thus putting us under to a pro tanto obligation to ourselves. The second-personal account implies that there is an interesting link between commitment and morality.

\section{German abstract:}

Nach Ruth Changs voluntaristischer Theorie der Commitments gebrauchen wir, wenn wir ein Commitment $\mathrm{zu}$ einer bestimmten Handlung, $\varphi$, eingehen, die ,normative Kraft ‘ unseres Willens und geben uns dadurch einen Grund $\varphi \mathrm{zu}$ tun, den wir sonst nicht hätten. Ich argumentiere, dass Changs Theorie alleine nicht über außreichende begriffliche Ressources verfügt, um die normative Signifikanz von Commitments mit ihrem angeblich fundamental willensbasierten Charakter zu vereinen. Ich schlage eine alternative, zweit-personale Theorie der Commitments vor, die dieses Problem vermeidet. Nach dieser Theorie ist der Willensakt, durch den wir ein Commitment eingehen, so beschaffen, dass wir uns dadurch selbst zur Verantwortung ziehen. Demzufolge erschaffen wir durch diesen Willensakt eine Verbindlichkeit gegen uns selbst. Die zweitpersonale Theorie der Commitments impliziert, dass Commitments auf interessante Weise mit der Moral verknüpft sind.

\section{Introduction}

Practical philosophers are increasingly interested in commitment as a normative relation (e.g., Chang 2013b, Liberman and Schroeder 2016, Shpall 2013, 2014). One lesson that can be drawn from recent work on this topic is that we can distinguish at least three types of commitment. First, having a certain attitude might commit us to forming some other attitude: my belief that I ought to $\varphi$ commits me to intending to $\varphi$; my belief that $p$, and that 
$p$ implies $q$, commits me to believing that $q$. We might refer to this type of commitment as "rational commitment" (Shpall 2013, 2014). Second, we might be committed to $\varphi$ by virtue of having promised to someone that we would $\varphi$. This is a paradigmatic example of what we might call "moral commitment" (Chang 2013b: 76-79, Shpall 2014). Third, we might be committed to $\varphi$ by being dedicated to $\varphi$. This type of commitment is implicated in utterances like 'I am committed to pursuing a career in philosophy'. I shall refer to this type of commitment as "internal commitment" (Chang 2013b: 76-79). Since this paper is concerned primarily with this latter type of commitment, I shall use 'commitment' to refer to internal commitment, except where I explicitly say otherwise.

Ruth Chang proposes a thoroughly voluntarist account of internal commitments, according to which they "essentially involve volitional activities" (2013b: 93, cf. 2009, 2013a, 2015). On this account, when we commit to $\varphi$ (e.g., pursue a certain project, maintain a certain relationship), we perform an act of will by which we give ourselves a reason to $\varphi$. According to Chang, the normativity of this reason does not depend on any reasons that we might have had prior to our act of will, nor on any normative principle that might apply to us. Instead, it is due entirely to the "normative powers" of our will (Chang 2013b: 101). Accordingly, Chang labels the reasons that arise from our commitments "voluntarist reasons" (ibid.).

The notion that we can give ourselves normative reasons by a mere act of will might strike some as implausible. However, for the purposes of this paper, I assume that it has at least some initial plausibility. My question is how we should conceive of the volitional act involved in commitment, and its relation to other parts of the normative domain, if we are to make sense of this notion. In particular, I critically assess Chang's account of commitment and argue that it does not offer sufficient resources to make sense of the idea that reasons created by a mere act of will possess genuine normative force.

The problem is roughly that, if an agent's voluntarist reasons to $\varphi$ are a function of her will, it is not clear how she can fail to act in accordance with those reasons. But, if an agent cannot fail to act in accordance with her voluntarist reasons, then it is questionable whether these reasons are normative. To avoid this problem, I suggest that we conceive of commitments as a relation of authority and accountability between ourselves and our own will. Accordingly, by making a commitment, we take up what Stephen Darwall calls "the second-person standpoint”, i.e., the stance from which we make and acknowledge demands on one another's will (2006). Since the second-person standpoint, on Darwall's account, grounds our moral obligations, the account of commitment that I present in this paper suggests an interesting connection between commitment and morality.

I start by outlining Chang's account of commitment (Section 2) and Darwall's notion of the secondperson standpoint (Section 3). Subsequently, I propose — pace Chang - that commitment should be understood as a second-personal relation between ourselves and our own will (Section 4). Finally, I highlight two important implications that my argument has for our understanding of commitments and morality: first, commitments give rise to obligations to ourselves and, second, there are formal moral constraints on what we can successfully commit to (Section 5). I conclude that commitments are not located outside the scope of morality, as sources of normativity that compete with moral considerations, but instead fall squarely within the moral domain (Section 6). 


\section{Chang on Commitment}

According to Chang, when we make a commitment to $\varphi$ we employ the normative powers of our will to give ourselves a reason to $\varphi$ that we would otherwise not have had. It is crucial to understand that Chang does not suggest that our commitment triggers some independent normative principle according to which our act of committing to $\varphi$ is a sufficient condition for our having a reason to $\varphi$ (2013b: 97-103). ${ }^{1}$ After all, while this suggestion would grant that our commitment plays some role in explaining the emergence of our reason to $\varphi$, the normativity of that reason would ultimately be underpinned by the normative principle that assigns this role to our commitment in the first place. In contrast, Chang believes that the volitional act involved in our commitment to $\varphi$ itself is that in virtue of which there is a normative reason for us to $\varphi$.

This raises the question of what kind of volitional act is involved in commitment. According to Chang, it is not merely a matter of deciding to $\varphi$, or of responding to some reason-giving aspect of $\varphi$-ing, e.g., its value (2013b: 79-81). Indeed, the willing involved in committing to $\varphi$ does not even take the act of $\varphi$-ing as its primary object. Instead, the volition involved in commitment is concerned, first and foremost, with our reasons to $\varphi$, and in particular with altering and supplementing these reasons. Specifically, when we commit to $\varphi$, we will, perhaps unconsciously, that some fact about $\varphi$-ing be a reason for us to $\varphi$ (Chang 2013b: 93). For example, by committing to a career in philosophy I will some fact about such a career have a normative, reason-giving significance that it otherwise would not have.

It is important to note that this implies that the volition involved in commitment takes a reflexive structure: in committing to $\varphi$, I will that a reason to $\varphi$ be created by this very act of will. In other words, I will, not only that a certain effect be achieved, but that it be achieved through my willing that it occur. Accordingly, Chang remarks that creating a voluntarist reason for yourself is a matter of "placing your will—your very agency — behind its being a reason" (2013b: 93). After all, if commitment is to be essentially volitional, it must consist in willing that one's own will be a source of reasons for oneself.

Note also that Chang explicitly distinguishes internal commitments from moral commitments (2013b: 76-79). She argues that moral commitments typically involve other persons and require their uptake if they are to exert any normative force. ${ }^{2}$ For example, the commitment involved in promising requires another person who accepts the promise and relies upon its fulfillment. By contrast, internal commitments essentially only involve a single person, willing that something be a reason for her. Therefore, according to Chang, the normative force of

\footnotetext{
${ }^{1}$ Chang is thus not using 'normative powers' in the (perhaps more familiar) sense of "normative powers conferred by rules" (McCormick 1972: 62).

${ }^{2}$ Of course, Chang does not say that all moral requirements involve uptake. She only says this of those moral requirements that are incurred by what we would ordinarily regard as a commitment.
} 
internal commitments cannot be explained by our obligations to others. ${ }^{3}$ I will discuss Chang's way of drawing the distinction between moral and internal commitments in Section 4.

Chang contends that her account vindicates "what is arguably Kant's deepest insight: that the will can be a source of normativity” (2013b: 104, cf. Kant 2011: 4:431). As opposed to Kant, however, Chang does not think that there is a close connection between the normative powers of our will and morality (2013b: 76-79). In particular, she does not think that there is a purely formal principle of willing that places constraints on the content of our voluntarist reasons (2013b: 108). Accordingly, she thinks that we could in principle give ourselves voluntarist reasons for almost anything, including immoral actions (2013a: 184, 2013b: 109). ${ }^{4}$ However, this does not mean that we will ever have all-things-considered reason to act immorally. This is because, on Chang's view, voluntarist reasons exist, and influence what we should do, all things considered, only in a very limited range of cases.

To understand this, it is important to note that Chang does not think that all our reasons are voluntarist reasons; some of our reasons are simply "given" independently of what we will (2013b: 104; pace Korsgaard 1996). On this "hybrid voluntarist" account, we can create voluntarist reasons, and in this way influence what we have all-things-considered reason to do, only if our given reasons have "run out" (ibid.). And our given reasons have run out if and only if, in a decision between two options, $\varphi$ and $\psi$, either (1) $\varphi$ and $\psi$ are in "equipoise" (i.e., the given reasons for $\varphi$ do not outweigh the given reasons for $\psi$, the given reasons for $\psi$ do not outweigh given reasons for $\varphi$, and neither are $\psi$ and $\varphi$ equally supported by given reasons) or (2) the given reasons favor one of the two options, but it is indeterminate how strongly they favor it (2013b: 103-110). Never will voluntarist reasons switch the "valence" of what we have all-things-considered reason to do (2013b: 105). That is, voluntarist reasons will never make it the case that we have all-things-considered reason to $\varphi$ in a situation where the given reasons favor $\psi$-ing. On the assumption that our given reasons are valenced against acting immorally, then, voluntarist reasons cannot make it the case that we have all-things-considered reason to act immorally (Chang 2013a: 184).

The hybrid character of Chang's account is not my main concern in this paper, but let me point out two things that will be relevant to my discussion in Section 5. First, hybrid voluntarism is in line with our moral intuitions only if we think that positing the existence of voluntarist reasons for immoral actions does not impugn a

\footnotetext{
${ }^{3}$ Note that internal commitment can nevertheless be a commitment to (one's relationship with) another person (Chang 2013b: 76). What distinguishes it from moral commitment, according to Chang, is that it does not require uptake by that person.

${ }^{4}$ I say 'almost anything' because Chang endorses "logical constraints" on commitment (2013b: note 39). Chang takes these constraints to bar against, for example, willing the fact that one is wearing red shoes to be a reason for donating a kidney to someone (ibid.). Yet, note that it is not clear how mere logic can impose such a constraint. It seems that, instead, Chang's suggestion covertly appeals to our intuitions about what the fact that one is wearing red shoes is a reason for, independently of our commitments. However, these intuitions should not be relevant to the question of what reasons we can create as a matter of will.
} 
meta-normative view provided that these reasons do not determine what we should do, all things considered. After all, according to Chang, whenever the strength with which our given reasons favor a morally permissible option over a morally impermissible one is indeterminate, we can give ourselves a voluntarist reason for the impermissible option, thus narrowing the normative gap between it and the permissible one. Chang anticipates that this might not be readily conceded and, consequently, contends that "there might, arguably, not be much difference in there being a reason that cannot change the valence and there being no reason at all” (2013a: 184). I return to this issue in Section 5.1.

Second, although voluntarist reasons for morally impermissible actions cannot change the valence, on Chang's account, morally dubious voluntarist reasons for permissible actions still might. Let me explain. As an example of an agent whose given reasons have 'run out', Chang introduces the case of Jane, who faces a hard choice between a career in banking and one in painting (2013a: 171). Suppose Jane wills the fact that, as a banker, she will be able to disappoint the hopes of poor people applying for loans to be a reason for her to become a banker. Since, by hypothesis, Jane's given reasons have run out, this reason will tip the scales in favor of the banking career. Yet, one might think that, although becoming a banker per se is not immoral, Jane would now be doing so for a morally dubious reason. I return to this train of thought in Section 5.2.

\section{The Second-Person Standpoint}

Setting aside Chang's view of commitments until Section 4, let me now introduce Darwall's second-personal framework. According to Darwall, the second-person standpoint, i.e., "the perspective you and I take up when we make and acknowledge claims on one another's conduct and will”, is the locus of a distinct class of practical reasons (2006: 3). He illustrates this by way of an example (2006: 5-10).

Suppose Arnold is standing on Bella's foot. Now, Arnold could acknowledge two types of reasons for removing his foot from on top of Bella's. On the one hand, Arnold could recognize that by standing on Bella's foot, Arnold is making Bella worse-off than she otherwise would be. In conjunction with the premise that wellbeing positively contributes to the state of the world in which it is realized, Arnold could thus conclude that he should remove his foot. Since the reason that Arnold would thereby recognize draws its normativity from features of states of the world, Darwall classifies it as a "state-of-the-world-regarding reason" (2006: 6). On the other hand, Arnold could recognize the fact that Bella can legitimately demand that Arnold remove his foot as a reason for action. This reason is not based on features of states of the world but on Bella 's legitimate authority to hold Arnold accountable for his conduct. Accordingly, Darwall classifies this reason as "authority-regarding" (2006: 247).

Darwall labels authority-regarding reasons "second-personal" because their "validity depends on presupposed authority and accountability relations between persons and, therefore, on the possibility of the reason's being addressed person-to-person” (2006: 8, italics deleted). He argues that second-personal reasons are implicated in the concept of moral obligation (2006: esp. chapter 5). He observes that "[w]hen we are morally obligated, we are not morally free to act otherwise; members of the moral community have the authority to hold us 
responsible if we do" (2006: 27). It follows that an agent is obligated to $\varphi$ if and only if she has a second-personal reason to $\varphi$.

Darwall holds that this has implications, not only for the form, but also for the content of our moral obligations (2006: 35-38). The reason is that, according to Darwall, "second-personal address", the attempt to give someone second-personal reasons by making demands on him, has certain "normative felicity conditions" (2006: 5). In particular, Bella's attempt to give Arnold a second-personal reason presupposes, on pain of unintelligibility, that Arnold can be held accountable for acting on this reason. And this implies that Arnold must be capable of holding himself accountable for acting in the required way.

To see this, consider that holding someone accountable is different from merely "goading" him in that it does not only aim to make them act in a certain way; it aims to make them act on their free and rational acknowledgment that the demand made of them is legitimate (Darwall 2006: 49-52). Now, since a second-personal reason is authority-regarding, it follows that Bella's demand implicitly aims at Arnold's withdrawing his foot out of respect for Bella's authority alone. But this requires that Arnold be able to internalise Bella's demand and address himself second-personally. Therefore, Bella's attempt to hold Arnold accountable implicitly presupposes that Bella is in turn accountable to Arnold. In particular, Arnold has the authority to demand of Bella that her demands on Arnold be justifiable to him.

But this means that even prior to any particular attempt to hold Arnold accountable, Bella must implicitly regard Arnold as a person with the standing to demand that Bella relate to him in a certain way — in a justifying, rather than in a goading manner (2006: 272). Thus, as participants in the practice of second-personal address who recognize ourselves and each other as such, we implicitly regard ourselves and one another as equal members of a moral community who are mutually accountable for respecting the second-personal standing of all persons (2006: 269-276).

In particular, we implicitly acknowledge that we are obligated to act in ways we can justify to one another from within the second-standpoint. Darwall suggests that, in this way, the necessary presuppositions of second-personal address vindicate a contractualist account of morality, according to which "an act is wrong if the act would be disallowed by a principle no one could reasonably reject our holding one another accountable for complying with” (2006: 301, cf. Hill 1989, Kumar 2003, Scanlon 1998: chapter 5). According to Darwall, an attempt to address someone second-personally that violates this basic contractualist requirement is invalid. More specifically, since such an attempt fails to meet the normative felicity conditions of second-personal address, it is not intelligible as such an address and "misfires" (2006: 44). That is, such an attempt will fail to give the addressee the second-personal reason it is intended to give her.

\section{A Second-Personal Account of Commitment}

With both Chang's account of commitment and Darwall's notion of the second-person standpoint in view, let me now turn to the main argument of this essay. I contend that Chang's account, by itself, does not have the conceptual resources to make sense of the notion that commitments are fundamentally volitional and nevertheless give rise to genuinely normative reasons. In order to remedy this problem, I propose a second-personal account of 
commitments, according to which commitment constitutes a relation of authority and accountability between ourselves and our own will.

Let us begin by having a closer look at the structure of second-personal address. I said that the secondpersonal reason that Arnold might recognise is authority-regarding in the sense that its normativity depends on Bella's authority to demand that Arnold remove his foot. Now, this means that, if Bella's authority to make this demand was in turn dependent on something else, e.g., facts about the state of the world that Arnold would bring about by removing his foot, then the reason that Arnold recognizes by recognizing Bella's authority would not be second-personal. After all, Bella's authority would not itself ground any of Arnold's reasons to remove his foot. Her authority would be entirely epistemic in nature; for it would merely enable her to point Arnold towards reasons that he independently has (Darwall 2006: 12-13).

From these considerations, Darwall concludes that the authority invoked by a second-personal reason is irreducibly second-personal (2006: 11-15). ${ }^{5}$ This authority is not exhausted by the standing to demand compliance with certain independently justified standards of conduct. Rather, when Bella demands that Arnold remove his foot, "she addresses a reason that would not exist but for her authority to address it" (2006: 13, italics added). Hence, second-personal authority is, most fundamentally, the "authority to demand respect for this very authority" (2006: 14, italics added). But this means that second-personal address, qua second-personal address, embodies the same reflexive structure which, as we saw in Section 2, is also characteristic of the volition involved in commitment. As commitment is a matter of willing that there be a reason which derives its normativity from this very act of will, so second-personal address is a matter of addressing a reason which derives its normativity from this very address.

We can see, then, that the volition involved in commitment embodies the structure which is definitive of second-personal reasoning. Now, one might respond that, by virtue of embodying this reflexive structure, the volition involved in commitment may well be 'authority-regarding', but not in the same sense as second-personal address. More specifically, one might hold that commitment is authority-regarding in the sense that it invokes the agent's authority to create reasons that derive their normativity from this very authority, but not in the sense that it involves a second party that is thereby being held accountable. Indeed, this seems to be Chang's view. After all, as we saw in Section 2, Chang argues that the commitments she is concerned with do not require uptake by another party. What is more, Chang thinks that, since we can create commitment-based reasons as a matter of will, terminating such reasons, through "uncommitment”, is also a matter of will (2013b: 94).

However, this is where the limitations of Chang's account come to the fore: if voluntarist reasons are to be genuinely normative, then there must be such a thing as a failure appropriately to respond to these reasons.

\footnotetext{
${ }^{5}$ Matthias Haase objects that Darwall's notion of second-personal address is not irreducibly second-personal because Arnold's authority over himself is conceptually prior to Bella's authority over him (2014: 145-146). Unfortunately, I cannot discuss this objection here.
} 
That is, it must be possible for an agent to be at fault for failing to $\varphi$ simply because she committed to $\varphi .{ }^{6}$ In other words, it must be possible to act against an existing commitment; and it is not clear that Chang's account allows for this possibility.

Now, Chang suggests that our commitments often have "downstream effects" (2013b: 95). That is, we often incur new 'given' reasons to $\varphi$ through actions that we perform as a result of having committed to $\varphi$ (e.g., because these actions give rise to new expectations on the part of others). One might argue that these downstream effects account for the possibility of being at fault for failing to do what one has committed to do. However, while this shows that we can be at fault for failing to $\varphi$, it does not show that we can be at fault for failing to $\varphi$ simply because we have committed to $\varphi$, and thus independently of our given reasons to $\varphi$. Accordingly, it seems that Chang's account, by itself, does not have the resources to explain why a commitment to $\varphi$, construed as a mere act of will, should give rise to a normative a reason to $\varphi$.

A natural and promising way to remedy this problem is to maintain that by the authority-regarding volition involved in making a commitment we actually bind ourselves. On this account, if by committing to $\varphi$ we are indeed to create a normative reason to $\varphi$, the act of will by which we invoke our authority to create such a reason must simultaneously be an act of holding ourselves accountable for recognizing this reason. Otherwise commitment will not amount to more than some kind of psychological force, and the authority involved in creating a commitment will be de facto rather than de jure. ${ }^{7}$

Put another way, if commitment did not involve holding ourselves accountable, it would be a matter of asserting the superiority of $\varphi$-ing in such a way as to render it difficult, psychologically speaking, to choose not to $\varphi$. But it would not be a matter of erecting a normative barrier against doing so. After all, by choosing not to $\varphi$

\footnotetext{
${ }^{6}$ I do not claim that, for a standard to be normative, it must be psychologically or physically possible to violate it. But we must at least be able to conceive of something that would count as falling short of that standard. Borrowing a distinction from Douglas Lavin, I am here appealing to the "logical interpretation of the error constraint", as opposed to its "imperatival interpretation" (2004: 426-427).

${ }^{7}$ One might argue that such de facto, psychological authority could still put us under normative pressure to $\varphi$ by triggering a rational requirement demanding consistency among our attitudes. However, this proposal cannot save Chang's account. First, on this proposal, the normativity of our commitments does not derive from the normative powers of our will but from an independently valid, general principle of rationality. Second, on the assumption that commitment is not based on de jure, normative authority, it is unclear why rationality should require that we act on them. Perhaps commitment involves the belief that we ought to $\varphi$, triggering the requirement against akrasia: if you believe that you ought to $\varphi$, you ought to intend to $\varphi$. However, this requirement does not give us a reason to $\varphi$ that could serve as a basis for rational choice when given reasons have 'run out'. After all, on the present proposal, the belief that we ought to $\varphi$, based on the commitment, is itself irrational; for, by hypothesis, commitment only involves de facto authority. Hence, if the requirement against akrasia gave us reason to $\varphi$, we would (irrationally) be 'bootstrapping' a reason into existence (Kolodny 2005). Therefore, the requirement is either not normative at all (see, e.g., Kolodny 2005), or it has "wide scope", in which case it merely requires that we either intend to $\varphi$ or drop the belief that we ought to $\varphi$ (see, e.g., Broome 1999).
} 
we would 'uncommit' from $\varphi$. Thus, we could not be at fault for failing to $\varphi$ simply by virtue of our commitment to $\varphi$. Therefore, if our will's authority to commit is to have the normative significance that Chang ascribes to it, it must be an authority over some person, i.e., it must make a difference to someone's normative situation. And in the case of commitments, this person can only be ourselves.

In other words, the volition involved in commitment is not only authority-regarding but also an instance of addressing ourselves second-personally. ${ }^{8}$ This means that there is a difference between uncommitting from $\varphi$, thus undoing one's voluntarist reason to $\varphi$, and simply failing to $\varphi$. This opens up conceptual space for the possibility of acting against an existing commitment to $\varphi$. After all, it makes a difference whether one is released from a relation of authority and accountability or simply neglects it. To use our example from Section 3, it matters if Arnold simply ignores Bella's legitimate demand that Arnold remove his foot or if Bella waives that demand. And, indeed, it seems plausible that the same is true of commitments. For example, there seems to be a difference between ceasing to pursue a career in philosophy despite my commitment and changing my commitments (perhaps in favor of some other career) altogether.

My account implies that, at the conceptual level, commitment does not involve a single, unified person. Rather, when we make a commitment we 'step outside of ourselves' to make a demand of ourselves. But this should not move us to reject the second-personal account of commitment. On the contrary, it is congenial to our ordinary understanding of commitments. First, as Chang acknowledges, there is not necessarily a one-to-one correspondence between our commitments and our decisions (2013b: 69). After all, we can make a commitment to $\varphi$ without ever consciously and deliberately deciding to do so, and we can decide to $\varphi$ without thereby making any commitment in the sense of giving ourselves a voluntarist reason. ${ }^{9}$ Although this does not, by itself, imply

\footnotetext{
${ }^{8}$ My reasoning in the last two paragraphs resembles an argument by Christine Korsgaard (1996: §4.2.2-4.2.4). However, whereas Korsgaard takes this argument to establish that reasons are inherently public, I employ it to suggest that genuinely normative authority-regarding reasons are second-personal reasons.

One might wonder why I am not simply adopting Korsgaard's account of normativity. Korsgaard argues that all reasons are self-legislated and second-personal in the sense that they involve a "thinking self" exerting governing authority over an "acting self” (1996: \$3.3.3, cf. 2007: 10). From this, via a transcendental argument, she purports to show that all reasons derive their normativity from Kantian autonomy and are therefore sanctioned by the Categorical Imperative test (1996: §3.4.7). Unfortunately, I cannot provide a detailed discussion here. In a nutshell, the problem with Korsgaard's account is that she ignores the irreducibly second-personal character of notions like obligation, legitimate authority, and accountability, which places them in a mode of practical reasoning that is fundamentally distinct from the merely first-personal mode of reasoning in which we must engage, insofar as we recognize any reasons whatsoever (Darwall 2006: chapter 9, 2007: 55). Accordingly, the second-personal (and moral) character of voluntarist reasons is not a matter of course; instead, it needs to be supported by an argument linking these reasons to irreducibly second-personal notions. My aim in this section is to provide such an argument. I am grateful to an anonymous reviewer asking me to clarify this.

${ }^{9}$ One might argue that Chang could invoke the distinction between committing and deciding in order to make room for the possibility of acting against one's commitments. However, while it is plausible that one can will that there be reason to $\varphi$ without deciding to $\varphi$ and vice versa, it is not obvious that one can decide not to $\varphi$ without thereby ceasing to will that there
} 
that commitment is second-personal, it suggests that there is a sense in which the committing agent and the deciding agent are not identical. Second, failure to fulfill one's commitments usually elicits 'reactive attitudes' of self-reproach, such as guilt and blame. By forming these attitudes, we implicitly hold ourselves accountable, taking up both the role of the person holding accountable and that of the person being held accountable (Darwall 2006: chapter 4, cf. Strawson 2003).

My proposal furthermore implies that Chang is wrong when she suggests that the difference between moral commitments and internal commitments is that the latter type of commitment does not involve uptake (see Section 2). After all, what I just argued suggests that, while internal commitments do not involve uptake by another person, they do require uptake by oneself. In particular, I argued that commitments cannot have the normative significance that Chang ascribes to them unless they involve the kind of authority by which one party holds another accountable. But if we are to hold ourselves to our commitments, we must accept them as binding in a way that resembles a promisee's acceptance of a promise.

In fact, I do not think that we have good reason to accept Chang's way of drawing the distinction between internal and moral commitments in the first place. To see this, note first that Chang acknowledges, if only in passing, that some moral commitments do not involve uptake by a separate person, but by oneself (2013b: 76).$^{10}$ Having made this concession, Chang then goes on to argue that internal commitments are not moral commitments (2013b: 76-79). However, her arguments for this claim do not even consider the possibility that internal commitments involve uptake by oneself. Instead, she merely points out differences between internal commitments and those moral commitments that involve uptake by another person. First, Chang argues that the commitments under discussion are "very much an internal affair" and therefore "not moral in the sense of essentially being relied upon by others" (2013b: 77). But this is beside the point since, as Chang has already acknowledged, moral commitments, too, can be entirely internal and independent of others' reliance upon their fulfillment (2013b: 76). Second, Chang argues that, when we make a moral commitment (e.g., a promise) to someone else, then additionally making a corresponding internal commitment adds further "significance" to the former (2013b: 77-78, cf. Shpall 2014: note 2). The idea seems to be that, if the internal commitment were a moral

be reason to $\varphi$. By contrast, the second-personal framework renders it possible to decide not to $\varphi$ without thereby ceasing to hold oneself accountable for $\varphi$-ing. Note that even if ceasing to will that there be reason to $\varphi$ is a distinct act of will which is not included in deciding not to $\varphi$, it is not clear how Chang's account can accommodate that. After all, if by committing to $\varphi$ we do not hold ourselves accountable, then why would 'uncommitting' from $\varphi$ be distinct from deciding not to $\varphi$ ? Chang does not offer conceptual resources to drive a wedge between these two notions.

${ }^{10}$ Interestingly, Chang even seems to follow Connie Rosati's argument that self-promises require uptake by oneself-and are second-personal_because there is a difference between breaking a self-promise and releasing oneself from it (Chang 2013b: note 5, Rosati 2011: 142-144). One might wonder in how far my argument differs from Rosati's, given that my characterization of commitments is very similar to her characterization of self-promises. Indeed, I take our respective analyses to be mutually supportive. Yet, my argumentative strategy differs importantly from Rosati's: while she bases her case on the intuitive notion that there is a difference between breaking a self-promise and releasing oneself from it, my argument invokes the reflexive structure of authority-regarding reasoning and its link to accountability to explain this intuitive notion. 
commitment, it would not constitute an additional act of commitment that contributes further significance. However, unless one neglects the possibility of uptake by oneself, it is difficult to see why there should not be two commitments involving uptake, one interpersonal and one intrapersonal. Chang's arguments thus do not give us reason to doubt that internal commitments involve uptake by oneself.

This is not to deny that there are important differences between commitments that involve uptake by another person and internal commitments. However, although I cannot argue this at length here, I think that these differences are artifacts of the different ways in which these commitments come about - and in particular the epistemic asymmetries between the two parties in the interpersonal case - rather than being due to the one kind requiring uptake while the other does not. ${ }^{11}$

\section{Implications}

I argued that commitments are instances of second-personal address, and thus voluntarist reasons are secondpersonal reasons. I now want to highlight two important implications that this argument has for our understanding of commitments and their relation to morality.

\subsection{Commitments as Obligations (to Oneself)}

As I noted in Section 3, second-personal reasons are the type of reasons that are implicated in the concept of obligation. To say that an agent is obligated to $\varphi$ is to say that she can legitimately be held accountable for failure to $\varphi$ - and thus that she has a second-personal reason to $\varphi$. We might say, then, that a second-personal reason, insofar as it rests on a relation of legitimate authority and accountability, constitutes a pro tanto obligation. It follows that, if voluntarist reasons are second-personal reasons, then commitments give rise to pro tanto obligations.

Indeed, that commitments give rise to obligations, rather than merely the type of reasons that recommend some course of action, finds independent support in our ordinary understanding of commitments. Alida Liberman and Mark Schroeder identify three key features that distinguish obligations from what we might call 'recommending reasons', and argue that commitments share these features (2016: 107-108, 117-118). ${ }^{12}$ First, following Sam Shpall, they point out that obligations are "strict" (Liberman and Schroeder 2016: 107, Shpall 2013 : 733, 2014: 158-160). More specifically, obligations present themselves as "demands" rather than "suggestions" and we are criticizable for failures to comply with them in a way in which we are not for failures to act on a recommending reason. Indeed, even if we are justified or excused in not fulfilling a certain (pro tanto) obligation, the

\footnotetext{
${ }^{11}$ Shpall makes a parallel argument to the effect that rational commitment is not, fundamentally, a different kind of relation than moral commitment (2014: 161-171). This raises the question of how rational commitment relates to internal commitment (see next note). I argued that internal and moral commitment share the same (second-personal) structure. If Shpall is right and moral and rational commitment are fundamentally the same kind of relation, does my account extend to rational commitment also? Unfortunately, I cannot answer this question within this essay.

${ }^{12}$ Strictly speaking, Liberman and Schroeder restrict their discussion to rational commitment $(2013,2014)$. However, their arguments seem to apply to internal commitments as well. This makes the question of how these commitments relate to rational commitments more pressing (see previous note).
} 
grounds for criticism need not vanish completely (ibid.). According to Darwall, this feature of obligations is due to their second-personal nature: if I am obligated to $\varphi$, I can legitimately be held accountable for failing to $\varphi$ (see Section 3). Since this relation of accountability does not wither away when my obligation to $\varphi$ is outweighed by other considerations, I might still be obligated to account for my action - e.g., by explaining or apologizing for what I did (Darwall 2006: 11-12).

As Liberman and Schroeder correctly observe, commitments share this feature of obligations. After all, as long as I am committed to pursue a career in philosophy, my failure to pursue such a career will at least in principle be subject to legitimate criticism — as I pointed out in Section 4, I might form reactive attitudes of selfreproach - even if my commitment is outweighed by other considerations. As Shpall pointedly remarks, if the same were true of recommending reasons, "then pretty much every act we performed, and every new attitude we formed, would be an occasion for such negative emotions" since, arguably, we constantly have recommending reasons for mutually exclusive courses of actions (2014: 160).

Second, Liberman and Schroeder observe that obligations have a different ontology than recommending reasons (2016: 107-108). In particular, recommending reasons essentially figure in a triadic relation: some fact, $F$, is a reason to perform an act, $\varphi$, for an agent, $A$. Obligations, by contrast, essentially figure in a dyadic relation: $A$ is obligated to $\varphi$. Thus, while it makes sense to ask $A$ what fact her recommending reason to $\varphi$ consists in, it would be nonsensical to ask the same of her obligation. Of course, we can ask how an obligation arose, and what justifies it. But this is different from the question what the obligation is. Again, the same is true of commitments. My commitment is to pursue a philosophy career, but it seems strange to ask what fact this commitment consists in.

Third, obligations, unlike recommending reasons, can be directed or bipolar (Liberman and Schroeder 2016: 108). That is, $A$ 's obligation to $\varphi$ can be owed to an individual or group, such that $A$ 's failure to $\varphi$ (lacking excuse or justification) wrongs this individual or group. Clearly, recommending reasons do not possess this feature. Commitments, on the other hand, seem to be the kind of thing that can be directed. This is clearest in the case of moral commitments: if $A$ promises $B$ to $\varphi$, her commitment is to $B$. Whether internal commitments can be directed as well is less obvious. In this paper, I cannot do justice to the vastness and complexity of the philosophical debate concerning the conditions under which an obligation is directed. ${ }^{13}$ But I would argue that, since moral commitments can be directed, there is no obvious reason to think that internal commitments cannot. After all, like moral commitments, internal commitments (a) are generated through uptake by a particular person, (b) are grounded in the relation of authority and accountability that is thereby established between the committing agent and the uptaking person, (c) often correspond to the uptaking person's discretional authority to release the committed agent, and (d) tend to elicit second-personal reactive attitudes, such as blame, if not fulfilled. Therefore, I suggest, we owe fulfillment of our internal commitments to ourselves. ${ }^{14}$

\footnotetext{
${ }^{13}$ For an overview of the debate, see May (2015).

${ }^{14}$ Following Kant and Hohfeld, it is commonly held that a duty is owed to someone if and only if that person has a (claim-) right to the duty's fulfillment (Hohfeld 1917, Kant 1996: 6:221-229). Since this view is typically conjoined with the notion
} 
We can conclude that commitments give us pro tanto obligations rather than recommending reasons. This has three important consequences for our understanding of commitments, which correspond to the three features of obligations that I just highlighted. First, since obligations continue to exert normative force and warrant criticism even when they are outweighed, our voluntarist reasons do not just fall by the wayside whenever they fail to make a difference as to what we have all-things-considered reason to do. Hence, Chang's remark that "there might, arguably, not be much difference in there being a reason that cannot change the valence and there being no reason at all” is not true in the case of voluntarist reasons (2013a: 184, also see Section 2). This might make Chang's claim that we can give ourselves voluntarist reasons to perform immoral actions harder to accept. I return to this topic in the next sub-section.

Second, since obligations - unlike recommending reasons - do not consist in a fact that counts in favor of an action, a further divergence from Chang's account is in order. In particular, committing to $\varphi$ cannot be a matter of willing some fact about $\varphi$-ing to be a reason to $\varphi$ (pace Chang 2013b: 93). But facts about $\varphi$-ing might still play a role in justifying our commitments. Ultimately, of course, the normativity of our commitments is underwritten by the normative powers of our will and thus, as I argued, by our second-personal authority. Yet, this authority is not unbounded. To the contrary, our second-personal reasons must be justifiable from within the second-person standpoint (also see Section 5.2). At this level, facts about $\varphi$-ing might be relevant. Moreover, facts about $\varphi$-ing might determine what we have to do to fulfill the obligation that results from our commitment to $\varphi$. For example, if I am committed to a career in philosophy and, as a matter of fact, a degree in philosophy is required for such a career, then I am committed to getting such a degree.

Third, since commitments give rise to second-personally grounded obligations whose fulfillment we owe to ourselves, Darwall's second-personal framework of morality accommodates obligations to oneself. ${ }^{15}$ Rather

that a duty corresponds to a claim-right only if it is appropriate to enforce its fulfillment, it is taken to imply that only enforceable duties can be directed (Hohfeld 1917, Kant 1996: 6:231-233). This, in turn, implies that commitments must be either enforceable or non-directed — and I certainly don't mean to suggest they are enforceable. However, while enforceability is a plausible condition for right-hood, I do not think that it is necessary for directedness. Accordingly, I do not think that there is a one-to-one correspondence between directed duties and claim-rights (cf. Cruft 2013: 204 and 209, Darwall 2013a: note 10, Wenar 2013: note 24).

Another potential objection to the claim that we owe fulfilment of our commitments to ourselves is that, on Darwall's account, obligations are directed only if they involve the obligor's individual second-personal authority to hold the obligee accountable personally (as opposed to the representative authority of every member of the moral community to hold her accountable impersonally; 2013a). It may seem that I have not shown that commitments involve the former rather than the latter kind of authority. However, as Simon May notes, Darwall's account does not provide a criterion to determine which kind of authority is involved in an obligation, other than whether it is directed or not (2015: 527-528).

15 The very coherence of the notion of obligations to oneself is sometimes challenged (Singer 1959: 202, cf. Kant 1996 6:417). I cannot provide a detailed discussion here. For two strong defences of the notion, see Schofield (2015) and Timmermann (2006). 
than being restricted to what we owe to each other, then, the second-person standpoint also governs what we owe to ourselves, as a matter of self-respect. ${ }^{16}$

\subsection{Commitments and Morality}

Since voluntarist reasons are second-personal reasons, commitment is subject to moral constraints, Chang's remarks to the contrary notwithstanding (2013b: 108-109). More specifically, since second-personal address necessarily presupposes, as part of its normative felicity conditions, that we are morally obligated to respect each other's equal second-personal standing, some immoral actions will never be supported by voluntarist reasons.

In particular, if an action is incompatible in principle with the contractualist requirement to act on principles that are justifiable from within the second-person standpoint to all members of the moral community, we cannot give ourselves voluntarist reasons to perform that action. Consider, for example, the action of enslaving a person (cf. Darwall 2006: 263-268). Not only does this action fail the contractualist requirement by being unjustifiable from within the second-person standpoint. In addition, slavery - by its very nature — denies the equal second-personal authority of the enslaved and thus involves the enslaver's refusal to even enter the hypothetical dialogue in which a second-personal justification of her conduct vis-à-vis the enslaved would have to take place. Hence, it seems, there cannot be any second-personal reasons, including voluntarist reasons, to perform actions of enslavement. Of course, one might still try to commit to such an action, but the attempt will not succeed at generating a normative reason. ${ }^{17}$ It follows that we do not have to rely on the priority of given reasons over vol-

\footnotetext{
${ }^{16}$ One might argue that this is not a novel insight since Darwall, following Thomas Hill Jr., acknowledges that "[g]iving little weight to one's own wishes and values, by being inappropriately deferential to those of others, can be [...] a failure to respect ourselves" (Darwall 2013b: 121, Hill 1973). However, as Hill explicitly notes, "[t]he duty to avoid servility is a duty to take a certain stance towards others and hence would be inapplicable if one were isolated on a desert island" (1973: 103, italics added). So, the relation to ourselves that underlies the duty to avoid servility does not generate any claims on us unless we also stand in certain relations to others. Hence, while this duty is in a sense self-regarding, it is not a clear case of a duty owed to ourselves. In Darwall's terminology, the duty might be based on the representative authority that we have over ourselves qua member of the moral community. And this authority merely mediates the claims that others make on us (2013a: 38, see previous note). (Note that, for the same reason, Darwall's insistence that accountability requires that we hold ourselves accountable from the second-person standpoint, mentioned in Section 3, does not imply that we have obligations to ourselves.) ${ }^{17}$ One might object that, even if $\varphi$-ing is utterly incompatible with the necessary presuppositions of second-personal address, the attempt to commit to $\varphi$ puts us under some normative pressure to $\varphi$. However, I would argue that insofar as there is such pressure, this is not because we are committed to $\varphi$, but because we believe that we are. And the normative force of this belief might in turn be explained by appeal to a wide-scope rational requirement (see note 7, cf. Broome 1999). Alternatively, one might argue that the normative force of this belief is due to a "rational commitment" (Shpall 2014: 158). This would seem to imply that these commitments are not second-personal (for otherwise they would be subject to moral constraints), making the question of how rational commitments relate to internal commitments all the more pressing (see notes 11 and 12).
} 
untarist reasons to make sure that we will never have all-things-considered reason to perform such an action (pace Chang, also see Section 2).

Note that this does not rule out the possibility that we end up being committed to an immoral action. Some actions are compatible in principle with the necessary presuppositions of second-personal address. By committing to these, we obligate ourselves to perform these actions. But the resulting obligations are pro tanto and can be outweighed by other moral considerations. In this way, we can end up being committed to an action which — under the circumstances — is morally impermissible (cf. Shpall 2014: 167-169).

However, I suggest that the moral constraints on commitment do rule out that we will ever create a voluntarist reason which is itself morally dubious. Recall the case of Jane, from Section 2, who willed the fact that, as a banker, she could disappoint the hopes of poor people as a reason for her to pursue a banking career. I noted that, while becoming a banker as such might be morally permissible, Jane's reason for doing so would be morally dubious. Now, I have already said that voluntarist reasons, qua obligations, do not consist in facts (see Section 5.1). This prevents Jane from making the fact that she could disappoint poor people into a voluntarist reason. Yet, as I also noted, this does not prevent facts from playing a role in the second-personal justification of voluntarist reasons. The moral constraints on commitment, however, do prevent some facts from playing such a role. After all, a second-personal reason is valid only if it is justifiable to all members of the moral community from within the second-person standpoint. This plausibly constrains the kinds of considerations that can be invoked against, and in favor of, particular instances of second-personal address. What exactly these constraints are is an issue that I cannot discuss at length here. ${ }^{18}$ But whatever they turn out to be, I expect that they will rule out invocations of considerations which - like Jane's appeal to the fact that, in banking, she could disappoint the hopes of poor people — themselves exemplify a certain disregard for persons' second-personal standing.

From the fact that commitments are subject to moral constraints in the ways I described in this subsection, it follows that voluntarist reasons do not only compete with moral reasons but are moral reasons. After all, if a voluntarist reason is validated by the necessary presuppositions of second-personal address, this means that the person who creates it can legitimately address it by invoking her second-personal authority. Accordingly, to recognize this reason - and to act as it directs if it goes undefeated - is a matter of respect for that person's equal second-personal standing.

\section{Conclusion}

When we make a commitment, we enter a second-personal relation with ourselves. I motivated this claim by suggesting that the reflexive type of willing involved in making a commitment cannot be normatively significant unless it invokes the legitimate authority to hold someone accountable. In the case of commitments, this 'some-

\footnotetext{
${ }^{18}$ On one promising proposal, a second-personal demand is legitimate only if its fulfillment would be conducive to the interests of its addresser, considered in her capacity qua second-personally competent being (Darwall 2006: 309-310, cf. Hill 1989: 768, Kumar 2003). This idea is structurally analogous to Rawls's notion of "primary goods" that are conducive to the interests of every citizen, qua free and equal moral person (1980: 525-526).
} 
one' must be the committing agent herself. Accordingly, the reasons to which our commitments give rise- our voluntarist reasons - are second-personal reasons. It follows that voluntarist reasons are subject to the moral constraints on second-personal address: they have to be justifiable to all members of the moral community from within the second-person standpoint. More positively, if these reasons are validated by the second-person standpoint, they emerge as pro tanto moral obligations to ourselves. In sum, then, commitment is not located outside morality, providing reasons that potentially compete with moral considerations, but placed firmly within the moral domain. Internal commitments are the intrapersonal equivalent of the moral commitments whose fulfillment we owe to others. ${ }^{19}$

\section{Bibliography}

Broome, John 1999: Normative Requirements, in: Ratio 12(4), 398-419.

Chang, Ruth 2009: Voluntarist Reasons and the Sources of Normativity, in: David Sobel and Steven Wall (eds.), Reasons for Action, Cambridge, UK, 243-271.

- 2013a: Grounding Practical Normativity: Going Hybrid, in: Philosophical Studies 164, 163-187.

— 2013b: Commitments, Reasons, and the Will, in: Russ Schafer-Landau (ed.), Oxford Studies in Metaethics: Volume 8, Oxford, 74-113.

- 2015: Transformative Choices, in: Res Publica 92(2), 237-282.

Cruft, Rowan 2013: Why is it Disrespectful to Violate Rights?, in: Proceedings of the Aristotelian Society 113(2), 201224.

Darwall, Stephen 2006: The Second-Person Standpoint: Morality, Respect, and Accountability, Cambridge, MA.

- 2007: Reply to Korsgaard, Wallace, and Watson, in: Ethics 118(1), 52-69.

- 2013a: Bipolar Obligations, in: Morality, Authority, and Law: Essays in Second-Personal Ethics I, Oxford, 2039.

— 2013b: The Value of Autonomy and Autonomy of the Will, in: Morality, Authority, and Law: Essays in SecondPersonal Ethics I, Oxford, 114-131.

Haase, Matthias 2014: For Oneself and Toward Another: The Puzzle about Recogition, in: Philosophical Topics 42(1), 114-152.

Hill, Thomas E. Jr 1973: Servility and Self-Respect, in: The Monist 57(1), 87-104.

- 1989: Kantian Constructivism in Ethics, in: Ethics 99, 752-770.

Hohfeld, Wesley N 1917: Fundamental Legal Conceptions as Applied in Judicial Reasoning, in: The Yale Law Journal 26(8), 710-770.

Kant, Immanuel 1996: The Cambridge Edition of the Works of Immanuel Kant: Practical Philosophy, Mary Gregor (ed.

\footnotetext{
${ }^{19}$ For detailed comments on previous drafts of this paper, I am indebted to Sarah Broadie, Ruth Chang, Stephen Darwall, Theron Pummer, Ben Sachs, Justin Snedegar, Jens Timmermann, and an anonymous reviewer. For feedback on material covered in this paper, I would also like to thank audiences at the Dublin Graduate Philosophy Conference 2016, the Gothenburg Responsibility Conference 2016, and the St Andrews Philosophy Graduate Research Seminar.
} 
and trans.), Cambridge, UK. Page references to Kant's works are to the page numbers of the Preußische Akademie Edition.

- 2011: Groundwork of the Metaphysics of Morals: A German-English Edition, Mary Gregor and Jens Timmermann (eds. and trans.), Cambridge, UK.

Korsgaard, Christine M. 1996: The Sources of Normativity, Cambridge, UK.

- 2007: Autonomy and the Second Person Wthin: A Commentary on Stephen Darwall's The Second-Person Standpoint, in: Ethics 118(1), 8-23.

Kolodny, Niko 2005: Why Be Rational?, in: Mind 114(445), 509-563.

Kumar, Rahul 2003: Reasonable Reasons in Contractualist Moral Argument, in: Ethics 114(1), 6-37.

May, Simon Căbulea 2015: Directed Duties, in: Philosophy Compass 10(8), 523-532.

McCormick, Neil 1972: Voluntary Obligations and Normative Powers, in: Aristotelian Society Supplementary Volume 46(1), 59-102

Lavin, Douglas 2004: Practical Reason and the Possibility of Error, in: Ethics 114, 424-457.

Liberman, Alida and Schroeder, Mark 2016: Commitment: Worth the Weight, in: Errol Lord and Barry Maguire (eds.), Weighing Reasons, Oxford, 104-133.

Rawls, John 1980: Kantian Constructivism in Moral Theory, in: Journal of Philosophy 77(9), 515-572.

Rosati, Connie 2011: The Importance of Self-Promises, in: Hanoch Sheinman (ed.), Promises and Agreements: Philosophical Essays, Oxford, 124-147.

Scanlon, Thomas M. 1998: What We Owe to Each Other, Cambridge, MA.

Schofield, Paul 2015: On the Existence of Duties to the Self (and Their Significance for Moral Philosophy), in: Philosophy and Phenomenological Research XC(3), 505-528.

Shpall, Sam 2013: Wide and Narrow Scope, in: Philosophical Studies 163(3), 717-736.

- 2014: Moral and Rational Commitment, in: Philosophy and Phenomenological Research LXXXVIII(1), 146172.

Singer, Marcus George 1959: On Duties to Oneself, in Ethics 69(3), 202-205.

Strawson, P. F. 2003: Freedom and Resentment, in: Gary Watson (ed.), Oxford Readings in Philosophy: Free Will, $2^{\text {nd }}$ edn., Oxford, 72-93.

Timmermann, Jens 2006: Kantian Duties to the Self, Explained and Defended, in: Philosophy 81(317), 505-530.

Wenar, Leif 2013: The Nature of Claim-Rights, in: Ethics 123(2), 202-229. 